\title{
In situ crystallization of low-melting ionic liquids
}

\author{
Angshuman R. Choudhury, Neil Winterton*, Alexander Steiner, Andrew I. Cooper and Kathleen A. \\ Johnson \\ Liverpool Centre for Materials and Catalysis, Department of Chemistry, University of Liverpool, Liverpool, L69 7ZD. \\ United Kingdom.
}

\section{Supplementary Information}


Table 1: Crystal Data

[emim]BF 4

(1)

\begin{tabular}{|c|c|c|c|c|c|}
\hline Formula & $\mathrm{C}_{6} \mathrm{H}_{11} \mathrm{~N}_{2} \mathrm{BF}_{4}$ & $\mathrm{C}_{8} \mathrm{H}_{15} \mathrm{NPF}_{6}$ & $\mathrm{C}_{9} \mathrm{H}_{15} \mathrm{~N}_{2} \mathrm{O}_{3} \mathrm{~F}_{3} \mathrm{~S}$ & $\mathrm{C}_{13} \mathrm{H}_{18} \mathrm{~N}_{2} \mathrm{O}_{4} \mathrm{~F}_{6} \mathrm{~S}_{2}$ & $\mathrm{C}_{11} \mathrm{H}_{20} \mathrm{~N}_{2} \mathrm{O}_{4} \mathrm{~F}_{6} \mathrm{~S}_{2}$ \\
\hline FW & 198.0 & 284.2 & 288.3 & 444 & 422.2 \\
\hline Colour & Colourless & Colourless & Colourless & Colourless & Colourless \\
\hline Crystal System & Monoclinic & Triclinic & Monoclinic & Triclinic & Orthorhombic \\
\hline Space Group & $P 2_{1} / n$ & $P \overline{1}$ & $P 2_{1} / n$ & $P \overline{1}$ & $P 2{ }_{1}{ }_{1} 2_{1}$ \\
\hline $\mathbf{Z}$ & 4 & 2 & 8 & 4 & 4 \\
\hline $\mathbf{a} / \AA \mathbf{A}$ & $8.7618(1)$ & $8.774(5)$ & $10.222(3)$ & $8.792(2)$ & $8.395(1)$ \\
\hline $\mathbf{b} / \AA \mathbf{A}$ & $9.3961(1)$ & $8.944(9)$ & $12.534(4)$ & $12.911(2)$ & $13.011(2)$ \\
\hline $\mathbf{c} / \AA$ & $11.4246(2)$ & $9.032(6)$ & $22.541(7)$ & $18.341(3)$ & $16.582(2)$ \\
\hline$\alpha /^{o}$ & 90.0 & $95.95(2)$ & 90.0 & $71.969(3)$ & 90.0 \\
\hline$\beta /^{\circ}$ & $98.720(1)$ & $114.93(1)$ & $93.28(1)$ & $83.335(2)$ & 90.0 \\
\hline$\gamma /^{\circ}$ & 90.0 & $103.01(3)$ & 90.0 & $88.815(2)$ & 90.0 \\
\hline Volume/ $\AA^{3}$ & $929.68(1)$ & $610.2(8)$ & $2883.2(2)$ & $1966.0(2)$ & 1811.1(1) \\
\hline Temp/K & 173 & 180 & 200 & 125 & 143 \\
\hline $\mathbf{D}_{\text {calc }} / \mathrm{gcm}^{-3}$ & 1.41 & 1.55 & 1.33 & 1.50 & 1.55 \\
\hline$\mu / \mathbf{m m}^{-1}$ & 0.141 & 0.282 & 0.26 & 0.346 & 0.371 \\
\hline Measured & 43379 & 16680 & 7144 & 19396 & 17521 \\
\hline Unique & 2984 & 3484 & 4487 & 5114 & 2595 \\
\hline$\theta_{\max } /{ }^{\circ}$, coverage & $36,0.68$ & $36,0.62$ & $27,0.70$ & $25,0.71$ & $25,0.81$ \\
\hline Parameters & 118 & 154 & 329 & 489 & 228 \\
\hline$R 1[I>2 \sigma(I)]$ & 0.044 & 0.045 & 0.072 & 0.053 & 0.051 \\
\hline$w R 2$ (all data) & 0.162 & 0.128 & 0.218 & 0.154 & 0.138 \\
\hline$\delta \rho_{\min , \max } / \mathbf{e} \AA^{-3}$ & $-0.231,0.345$ & $-0.293,0.330$ & $-0.430,0.412$ & $-0.279,0.660$ & $-0.425,0.356$ \\
\hline GooF & 1.091 & 1.057 & 0.923 & 1.099 & 1.052 \\
\hline
\end{tabular}


Crystal data were collected on Bruker Apex (3 -5) and Bruker Apex2 (1 and 2)

diffractometers, respectively, using $\operatorname{MoK}_{\alpha}$-radiation $(\lambda=0.71073 \AA)$. The experimental set-up did not allow full $\omega$-rotations. Hence, the data sets are of lower coverage. Crystal structures were refined with full-matrix least squares on $F^{2}$ using all data (SHELXTL crystal structure solution software). Non-hydrogen atoms were refined anisotropically. Hydrogen atoms were fixed on geometrically ideal positions during the refinement. The free refinement of hydrogen atom parameters gave low data/parameter ratios and led to high correlations. 
Table 2: Intermolecular interactions

\begin{tabular}{|c|c|c|c|c|c|}
\hline Ionic Liquid & B-D $\cdots A$ & $\mathbf{B} \cdots \mathbf{A}(\AA)$ & $\mathbf{D} \cdots \mathbf{A}(\AA))$ & $\angle \mathbf{B}-\mathbf{D} \cdots \mathbf{A}\left({ }^{\mathbf{0}}\right)$ & Symmetry \\
\hline \multirow[t]{5}{*}[\mathrm{emim}]{$\mathrm{BF}_{4}$} & C4-H4 ‥F3 & $3.230(2)$ & $2.378(1)$ & $147.6(1)$ & $\mathrm{x}, \mathrm{y}, \mathrm{x}$ \\
\hline & $\mathrm{C} 8-\mathrm{H} 8 \mathrm{~B} \cdots \mathrm{F} 1$ & $3.323(2)$ & $2.447(1)$ & $151.6(1)$ & $\mathrm{x}, \mathrm{y}, \mathrm{z}$ \\
\hline & $\mathrm{C} 2-\mathrm{H} 2 \cdots \mathrm{F} 4$ & $3.140(1)$ & $2.271(1)$ & $150.3(1)$ & $3 / 2-x, y+1 / 2,1 / 2-z$ \\
\hline & C5-H5 $\cdots$ F2 & $3.462(2)$ & $2.516(1)$ & $168.5(1)$ & $\mathrm{x}+1 / 2,3 / 2-\mathrm{y}, \mathrm{z}-1 / 2$ \\
\hline & C8-H8A $\cdots$ F3 & $3.383(2)$ & $2.594(1)$ & $139.6(1)$ & $2-\mathrm{x}, 2-\mathrm{y}, 1-\mathrm{z}$ \\
\hline \multirow{7}{*}[\mathrm{bmim}]{$\mathrm{PF}_{6}$} & $\mathrm{C} 2-\mathrm{H} 2 \cdots \mathrm{F} 5$ & $3.234(3)$ & $2.354(2)$ & $152.2(1)$ & $\mathrm{x}, \mathrm{y}, \mathrm{z}$ \\
\hline & $\mathrm{C} 2-\mathrm{H} 2 \cdots \mathrm{F} 3$ & $3.192(4)$ & $2.597(3)$ & $120.4(1)$ & $2-x, 1-y, 1-z$ \\
\hline & $\mathrm{C} 4-\mathrm{H} 4 \cdots \mathrm{F} 2$ & $3.380(4)$ & $2.448(3)$ & $163.6(1)$ & $2-\mathrm{x},-\mathrm{y}, 1-\mathrm{z}$ \\
\hline & C10-H10B $\cdots \mathrm{F} 4$ & $3.434(4)$ & $2.490(3)$ & $148.0(2)$ & $2-\mathrm{x},-\mathrm{y}, 1-\mathrm{z}$ \\
\hline & C6-H6B $\cdots \mathrm{F} 6$ & $3.309(3)$ & $2.533(2)$ & 137.9(1) & $\mathrm{x}+1, \mathrm{y}, \mathrm{z}+1$ \\
\hline & C5-H5 $\cdots$ F3 & $3.418(3)$ & $2.590(2)$ & $144.6(1)$ & $\mathrm{x}+1, \mathrm{y}, \mathrm{z}+1$ \\
\hline & C9-H9C $\cdots$ F3 & $3.503(4)$ & $2.577(2)$ & $162.1(2)$ & $\mathrm{x}, \mathrm{y}, \mathrm{z}+1$ \\
\hline \multirow[t]{6}{*}{ [bmim]OTf } & $\mathrm{C} 2-\mathrm{H} 2 \cdots \mathrm{O} 1$ & $3.097(7)$ & $2.247(4)$ & $151.7(4)$ & $\mathrm{x}, \mathrm{y}, \mathrm{z}$ \\
\hline & C13-H13-O6 & $3.112(7)$ & $2.265(4)$ & $151.1(4)$ & $\mathrm{x}, \mathrm{y}, \mathrm{z}$ \\
\hline & $\mathrm{C} 4-\mathrm{H} 4 \cdots \mathrm{O} 5$ & $3.338(6)$ & $2.439(4)$ & $162.7(3)$ & $-\mathrm{x}-1 / 2, \mathrm{y}-1 / 2,3 / 2-\mathrm{z}$ \\
\hline & C6-H6B $\cdots \mathrm{O} 2$ & $3.355(7)$ & $2.569(4)$ & $138.2(4)$ & $-x-1 / 2, y-1 / 2,3 / 2-z$ \\
\hline & $\mathrm{C} 15-\mathrm{H} 15 \cdots \mathrm{O} 2$ & $3.342(6)$ & $2.433(4)$ & $165.5(3)$ & $-\mathrm{x}-1 / 2, \mathrm{y}-1 / 2,3 / 2-\mathrm{z}$ \\
\hline & $\mathrm{C} 21-\mathrm{H} 21 \mathrm{~B} \cdots \mathrm{O} 1$ & $3.381(7)$ & $2.442(4)$ & $166.0(3)$ & $-\mathrm{x}-1 / 2, \mathrm{y}-1 / 2,3 / 2-\mathrm{z}$ \\
\hline \multirow[t]{6}{*}{ [hexpy]NTf 2} & $\mathrm{C} 1-\mathrm{H} 1 \cdots \mathrm{O} 1$ & $3.216(6)$ & $2.56(5)$ & $135(4)$ & $\mathrm{x}, \mathrm{y}, \mathrm{z}$ \\
\hline & $\mathrm{C} 1-\mathrm{H} 1 \cdots \mathrm{O} 3$ & $3.379(5)$ & $2.60(5)$ & $152(4)$ & $\mathrm{x}, \mathrm{y}, \mathrm{z}$ \\
\hline & C14-H14 ...O7 & $3.402(6)$ & $2.53(5)$ & $154(4)$ & $\mathrm{x}, \mathrm{y}, \mathrm{z}$ \\
\hline & C14-H14…06 & $3.143(6)$ & $2.46(5)$ & $129(4)$ & $\mathrm{x}, \mathrm{y}, \mathrm{z}$ \\
\hline & $\mathrm{C} 8-\mathrm{H} 8 \cdots \mathrm{F} 1$ & $3.380(6)$ & $2.61(4)$ & $135(4)$ & $\mathrm{x}-1, \mathrm{y}, \mathrm{z}$ \\
\hline & $\mathrm{C} 18-\mathrm{H} 18 \cdots \mathrm{O} 4$ & $3.202(5)$ & $2.26(4)$ & $166(4)$ & $-\mathrm{x},-\mathrm{y}+2,-\mathrm{z}$ \\
\hline \multirow[t]{6}{*}{ [bmpyr] $\mathbf{N T f}_{2}$} & 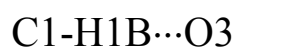 & $3.483(5)$ & $2.58(1)$ & $151(1)$ & $1 / 2-x, 1-y, 1 / 2+z$ \\
\hline & C6-H6A $\cdots$ O3 & $3.479(5)$ & $2.55(1)$ & $156(1)$ & $1 / 2-x, 1-y, 1 / 2+z$ \\
\hline & $\mathrm{C} 3-\mathrm{H} 3 \mathrm{~A} \cdots \mathrm{O} 1$ & $3.537(5)$ & $2.60(1)$ & $159(1)$ & $1 / 2-x, 1-y, 1 / 2+z$ \\
\hline & $\mathrm{C} 4-\mathrm{H} 4 \mathrm{~A} \cdots \mathrm{O} 2$ & $3.529(5)$ & $2.59(1)$ & $158(1)$ & $\mathrm{x}+1 / 2,3 / 2-\mathrm{y}, 1-\mathrm{z}$ \\
\hline & C5-H5B $\cdots \mathrm{O} 3$ & $3.343(5)$ & $2.52(1)$ & $140(1)$ & $x+3 / 2,3 / 2-y, 1-z$ \\
\hline & C7-H7A $\cdots \mathrm{O} 3$ & $3.439(5)$ & $2.52(1)$ & $155(1)$ & $x+3 / 2,3 / 2-y, 1-z$ \\
\hline
\end{tabular}




\section{DSC Measurements}

DSC measurements were carried out on a Perkin Elmer Diamond HyperDSC $®$, calibrated using an indium primary standard, with solid-solid transitions for cyclohexane and ethylbenzene as supplementary low temperature standards.

The ionic liquids 1 - 5 were all purchased from Merck GgaA, to a HP (high purity) specification that included a water level of $<100 \mathrm{ppm}$. Sealed containers of ionic liquids were opened only in a nitrogen-filled glove box in which all sample handling took place.

Ionic liquid samples were sealed in Al pans (in the nitrogen-filled glove box) with an empty Al pan was used as reference.

DSC measurements were carried out in a helium atmosphere on samples of different sizes and the samples initially examined using different rates of heating and cooling.

All of the DSC data discussed in the manuscript were measured on 7-12mg samples (weighed to 5 decimal places using a digital analytical balance).

Samples of ionic liquid 1 - 4 were cooled and heated at $5{ }^{\circ} \mathrm{C} / \mathrm{min}$ in the range $+40{ }^{\circ} \mathrm{C}$ to $180^{\circ} \mathrm{C}$. The range for ionic liquid 5 was $+80{ }^{\circ} \mathrm{C}$ to $-180^{\circ} \mathrm{C}$. 


\section{In situ crystallization experiments}

Prior knowledge of the thermal behavior of the materials studied enabled conditions for the in situ crystallization experiments using the 'Challenge' Optical Heating and Crystallization Device (Bruker AXS) to be defined. Differences in heating and cooling conditions in the DSC and OHCD experiments, and the possible formation of polymorphs, lead us, at present, to be cautious about correlating definitively the structure revealed by crystallography with the dominant transition in the DSC. Future low temperature X-ray diffraction studies will examine polymorph formation and associated phase changes, both known to be affected by thermal history and the presence of impurities.

In the zone-melting experiments, laser intensity is increased over 1-2 minutes from zero just to melt the polycrystalline material (a value that is different from ionic liquid to ionic liquid). The molten zone is moved along the capillary at about $3 \mathrm{~cm} /$ hour. Intensity was reduced to zero within 2-5 minutes after each scan.

The ionic liquid sample was monitored visually using a NTSC-Digital Video Camera (Model LCL-211H, Watec America Corp., USA), with a magnification of 1x-3x.

As the capillary containing the liquid was mounted vertically in the diffractometer (fitted with an Oxford Cryosystem cooling device) it was not possible to collect data with $\phi=$ 
$90^{\circ}$ and $180^{\circ}$. Only a single $\omega$ scan, with $\phi=0^{\circ}$, was recorded and used for structure solution and refinement. As a result, the completeness of data is in the range $70-80 \%$, less than usual for single crystal data. 


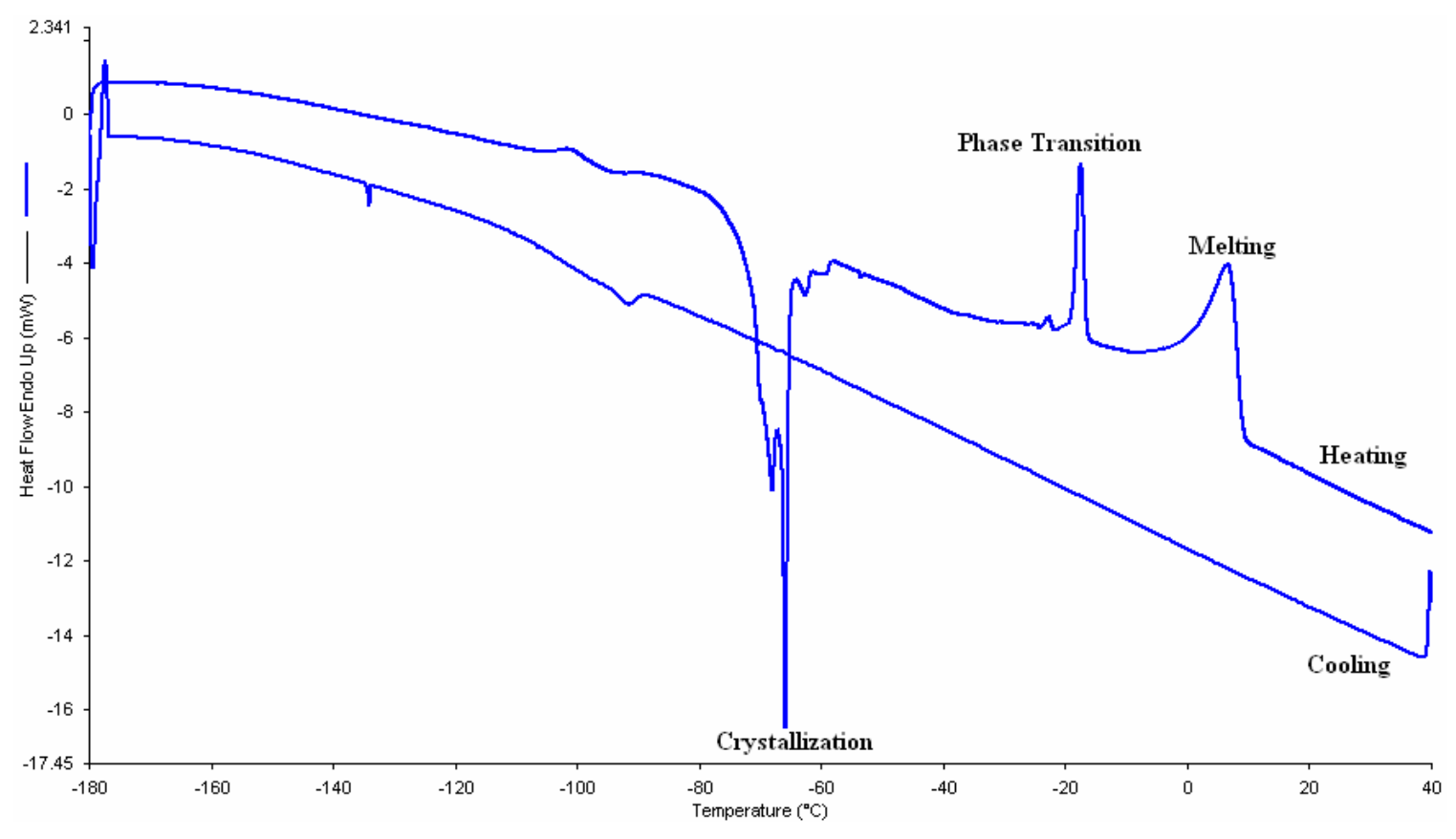

DSC Plot for [emim]BF 4 (1)

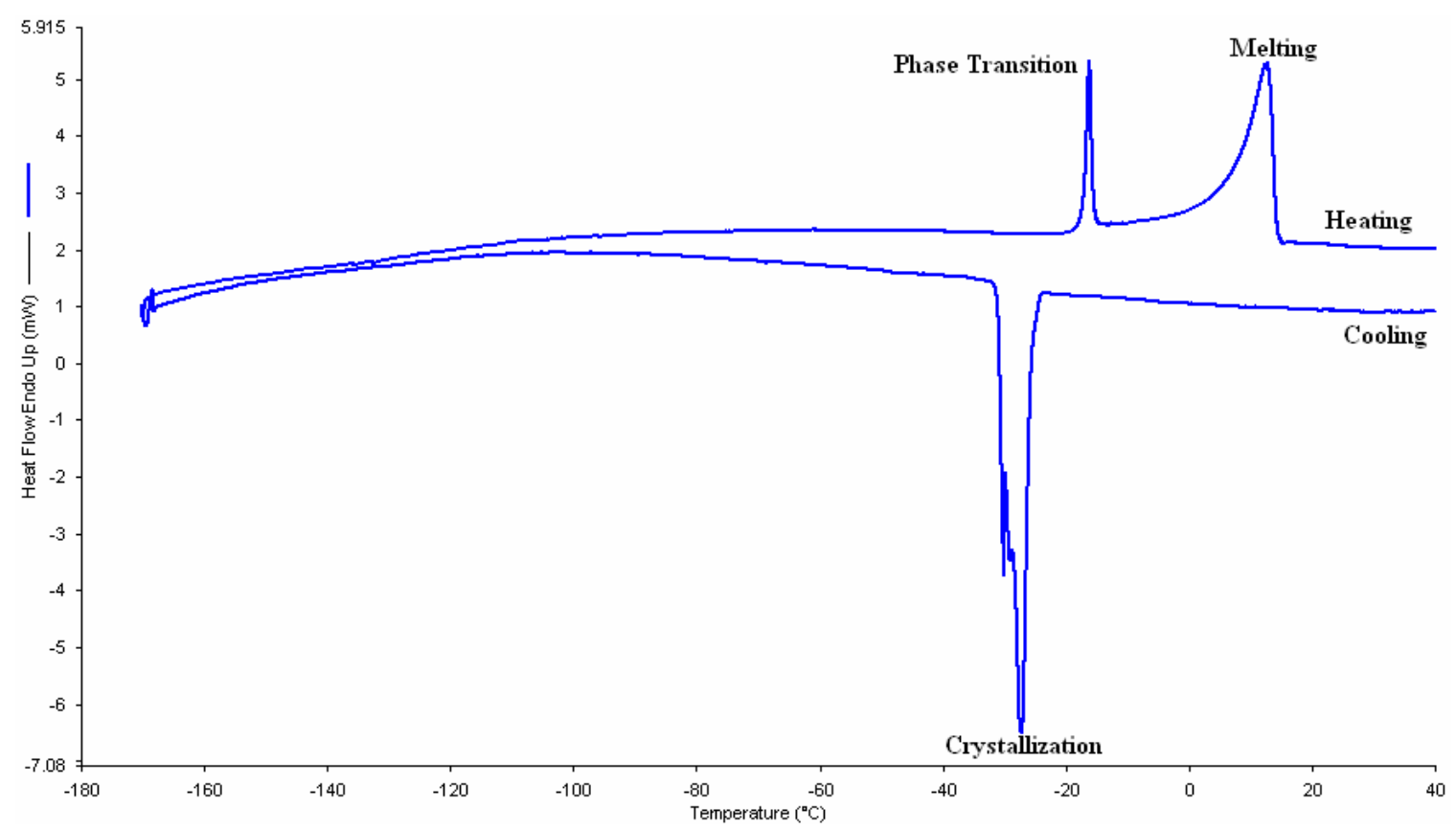

DSC Plot for [bmim]OTf (3) 


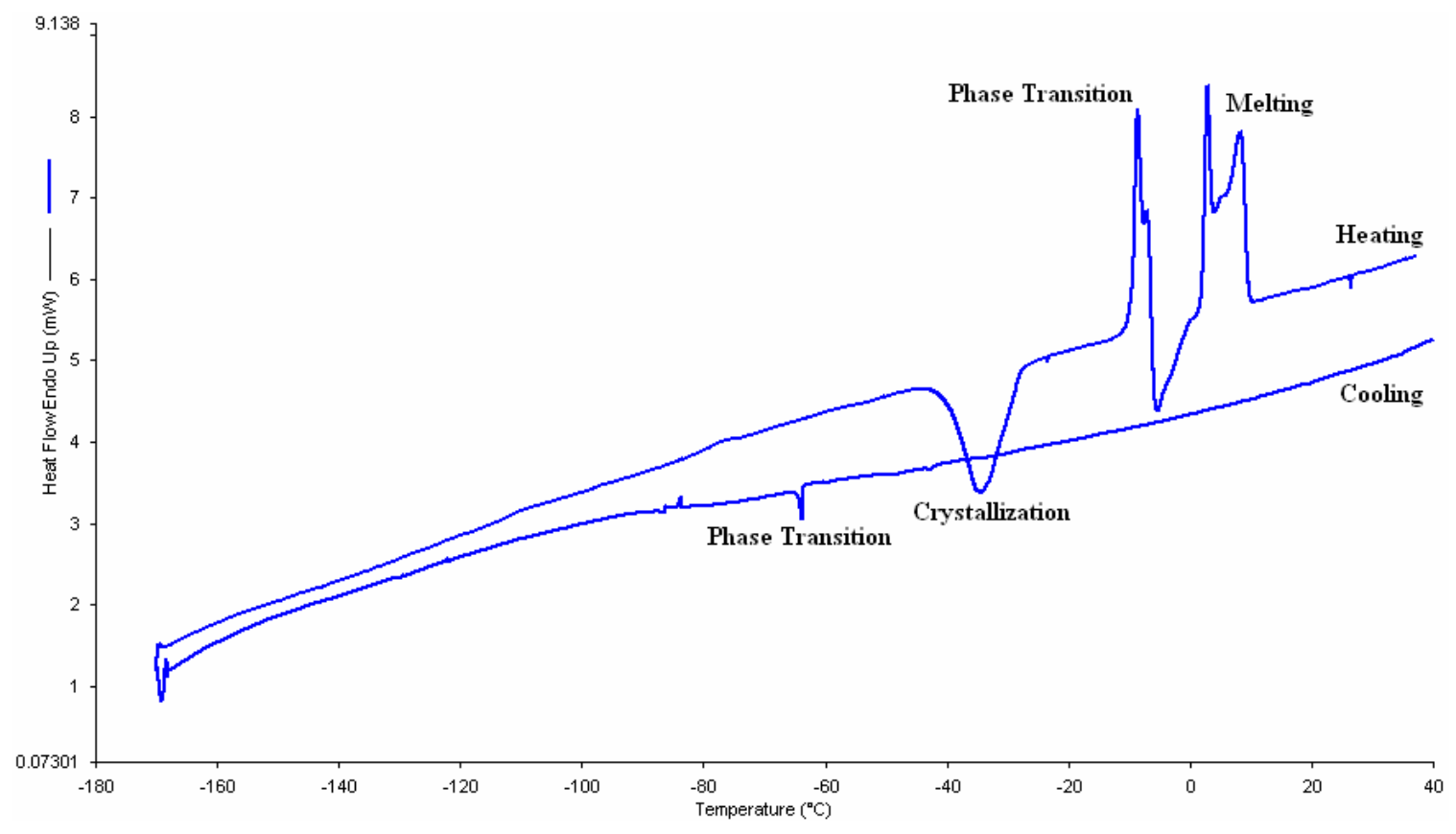

DSC Plot for [bmim] $\mathrm{PF}_{6}$ (2)

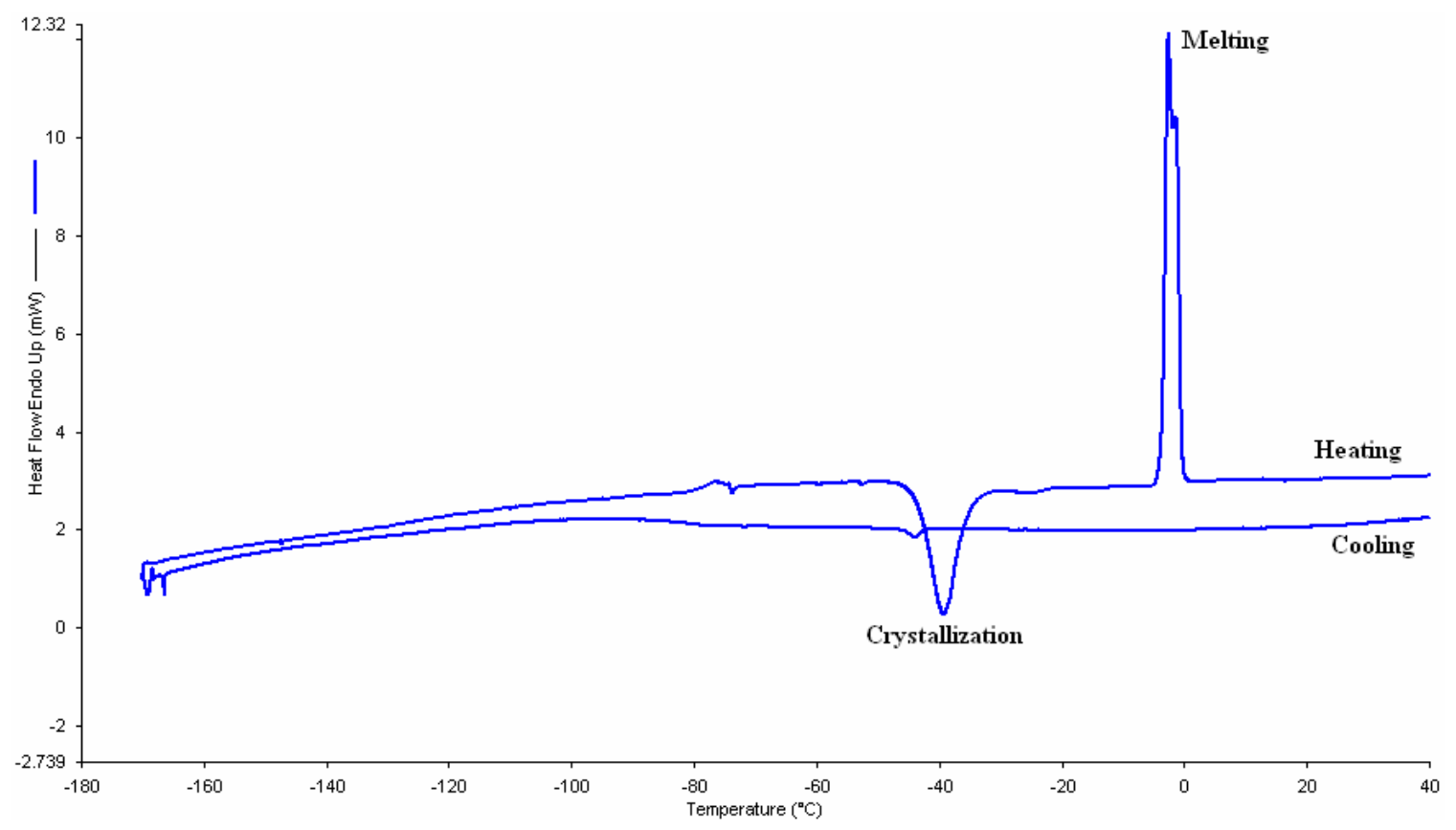

DSC Plot for [hexpy]NTf ${ }_{2}(4)$ 


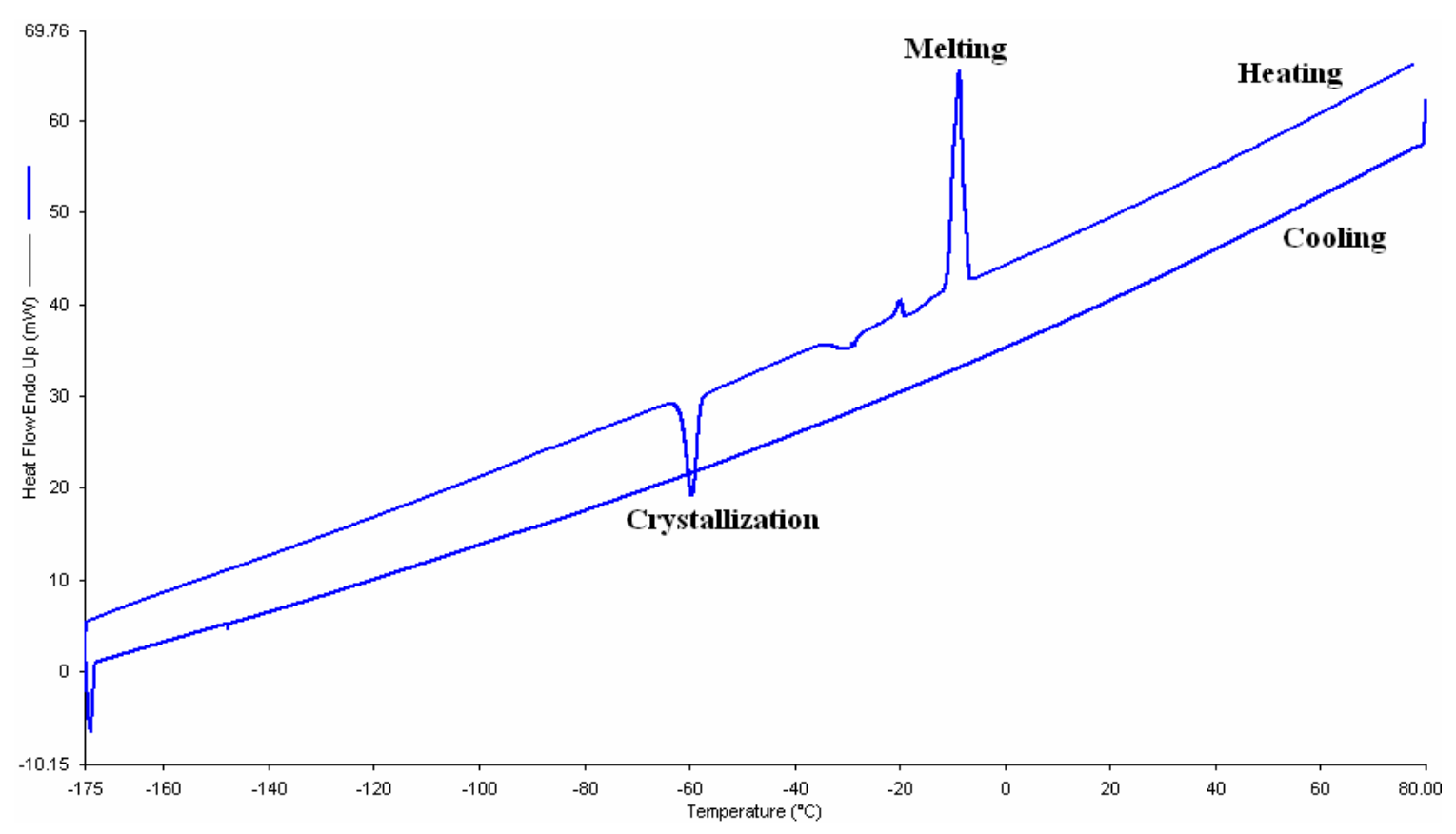

DSC Plot for [bmpyr]NTf $f_{2}$ (5) 


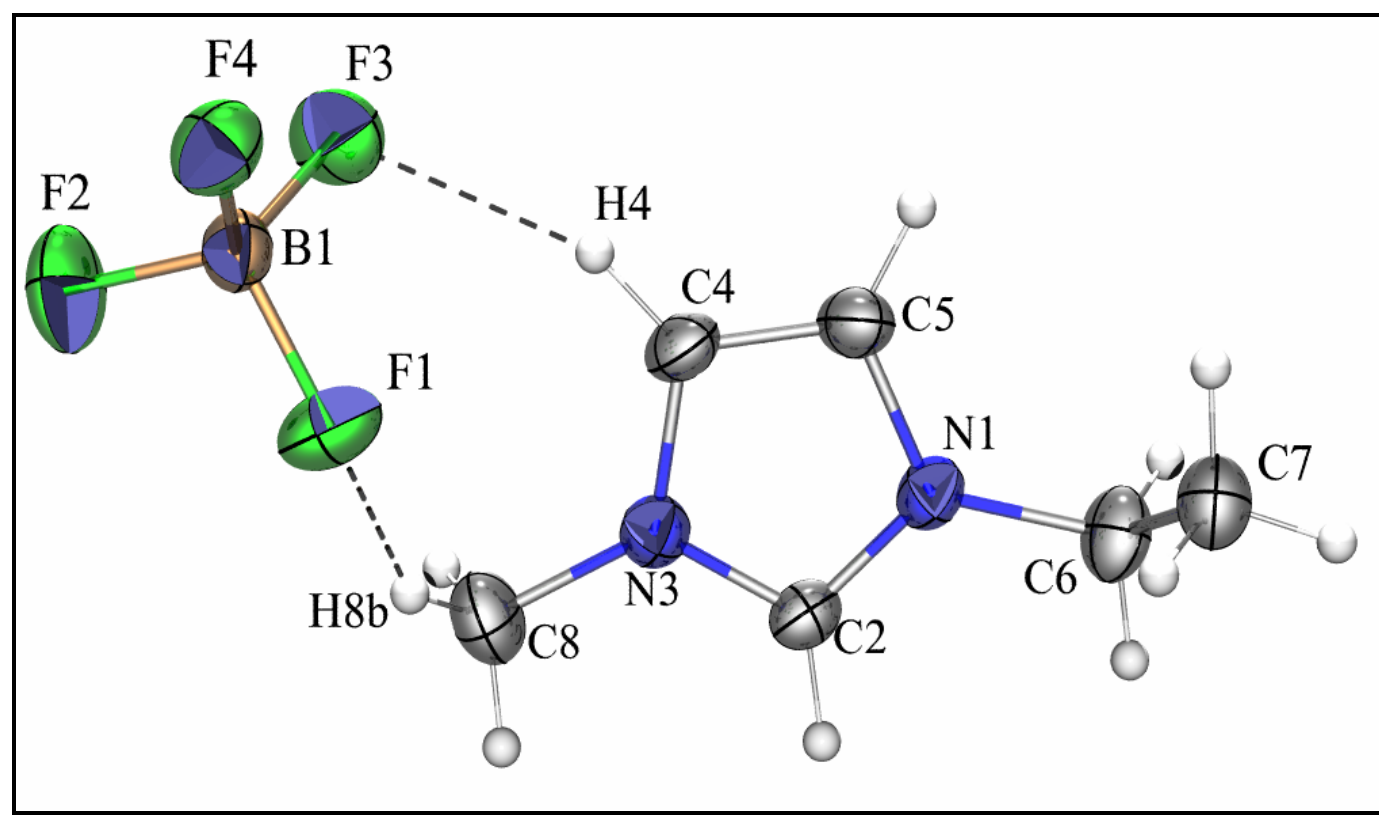

ORTEP of [emim]BF 4

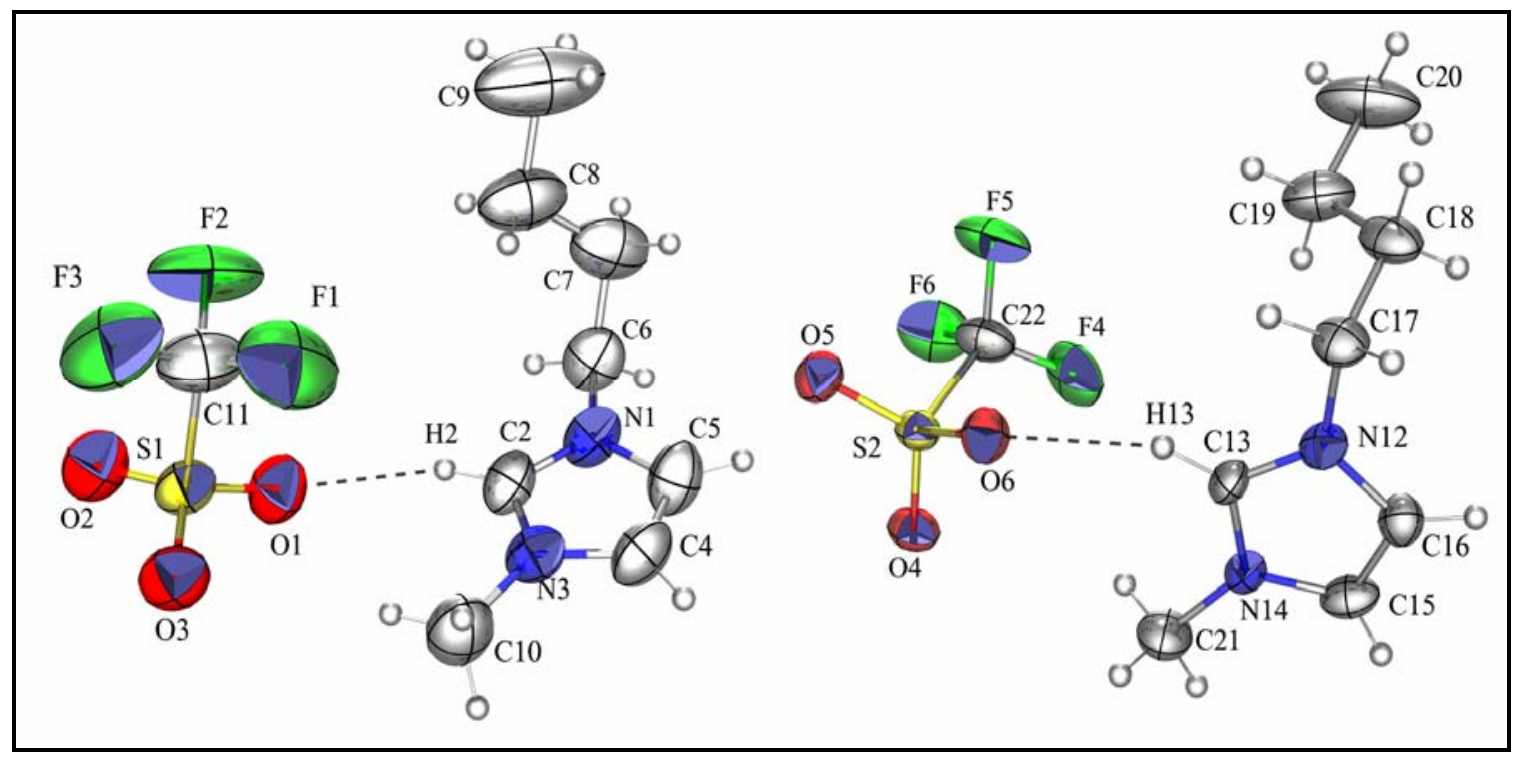

ORTEP of [bmim]OTf 

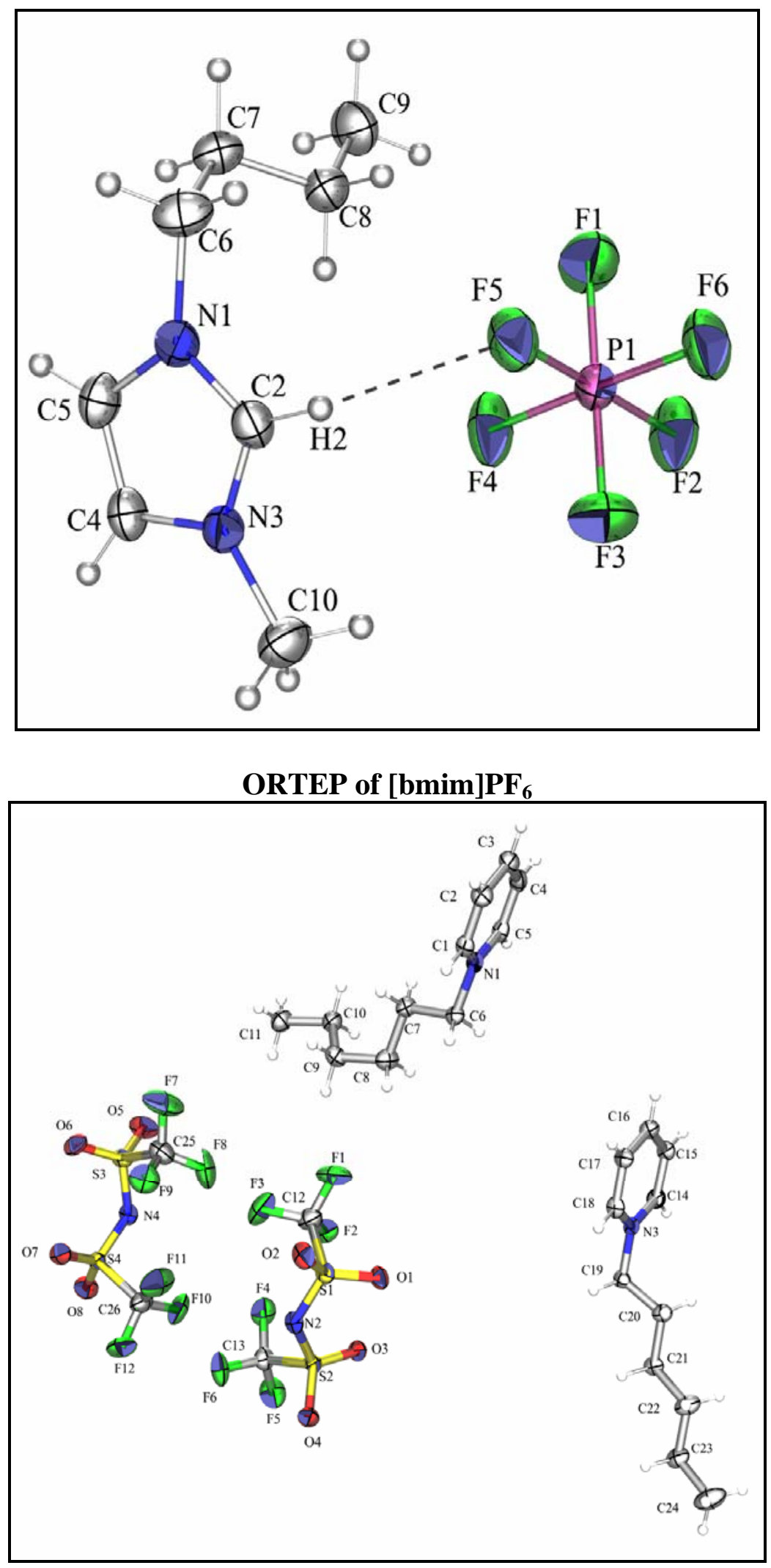

ORTEP of [hexpy]NTf $f_{2}$ 


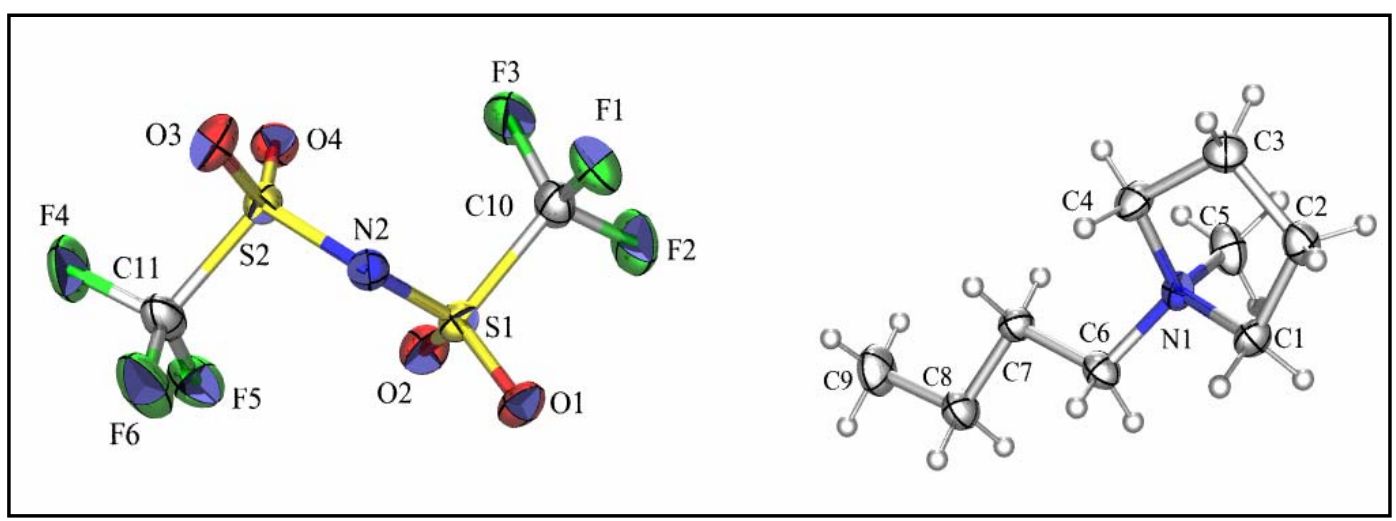

ORTEP of [bmpyr]NTf 


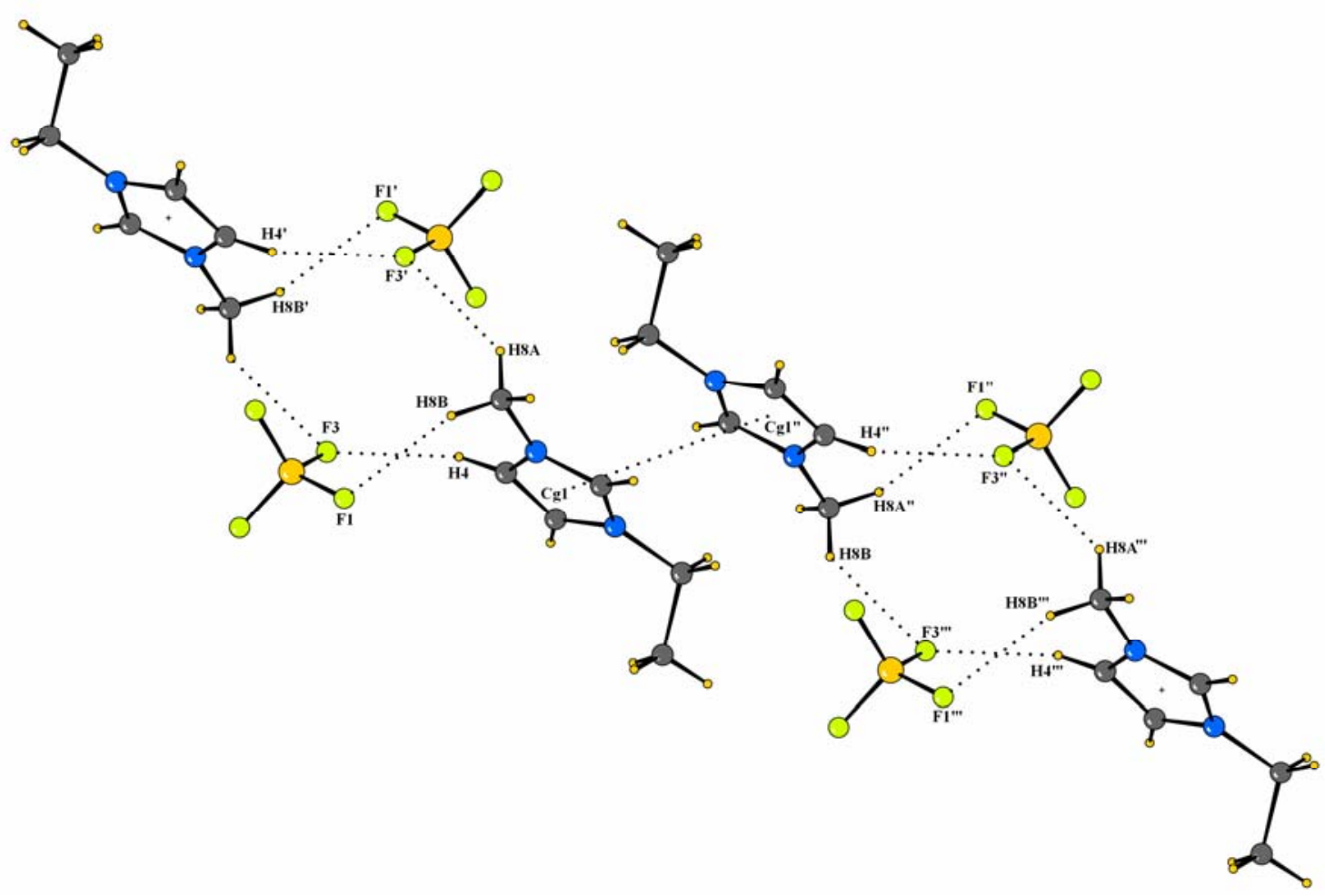

Intermolecular interactions in $[\mathrm{emim}] \mathrm{BF}_{4}(1)$

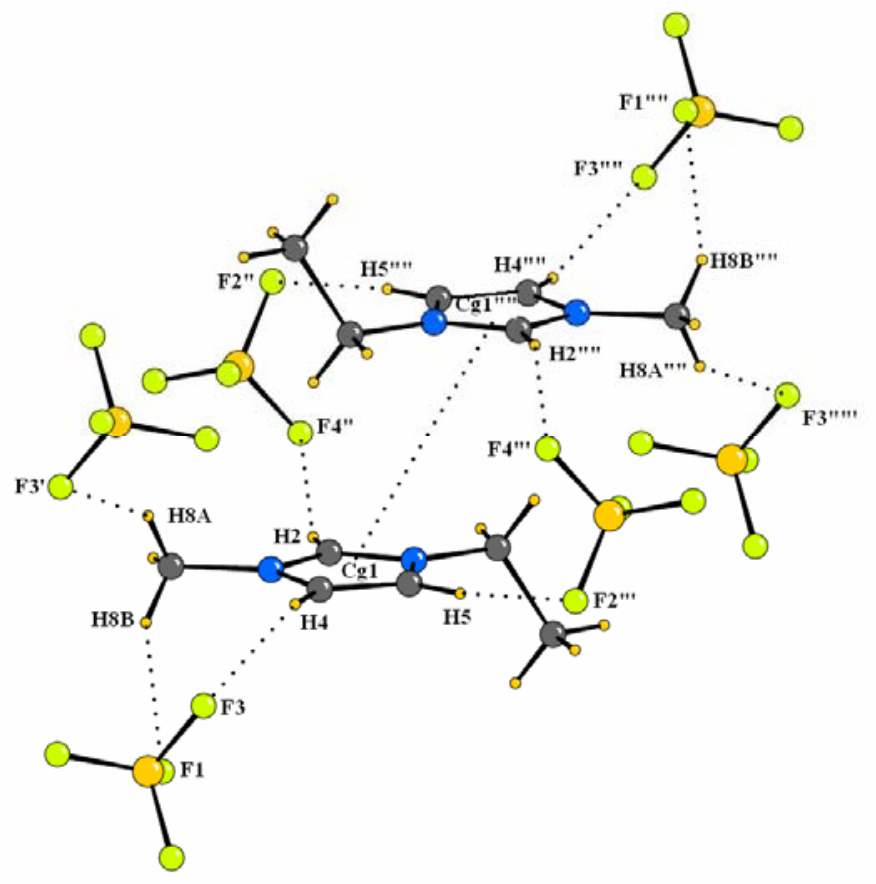

Intermolecular interactions in [emim]BF 4 (2) 


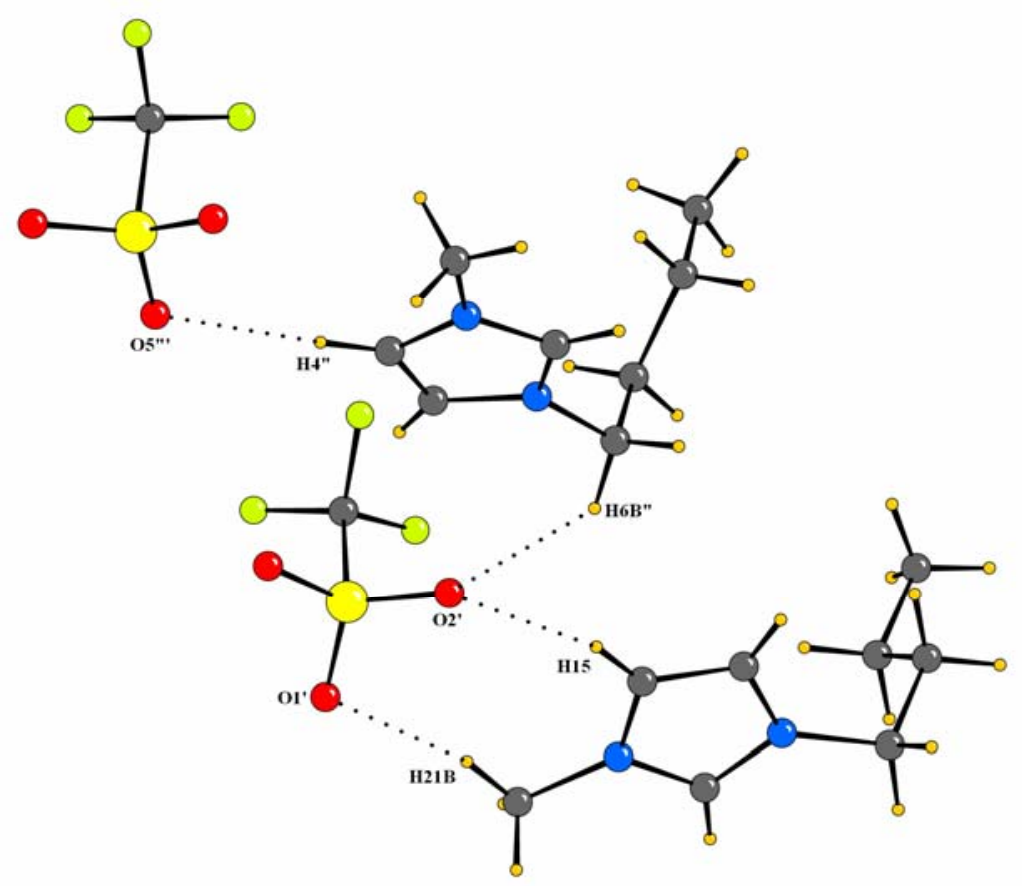

Intermolecular interactions in [bmim]OTf

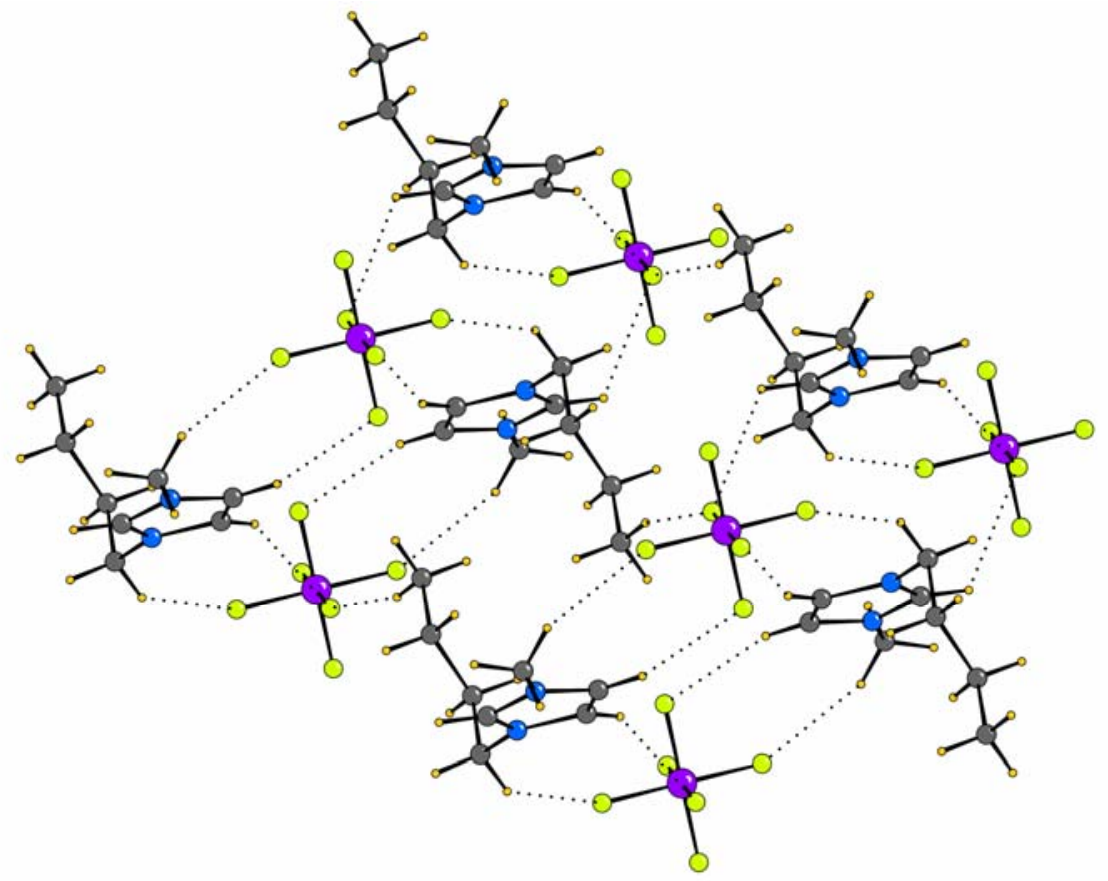

Intermolecular interactions in $[\mathrm{bmim}] \mathbf{P F}_{6}$ 


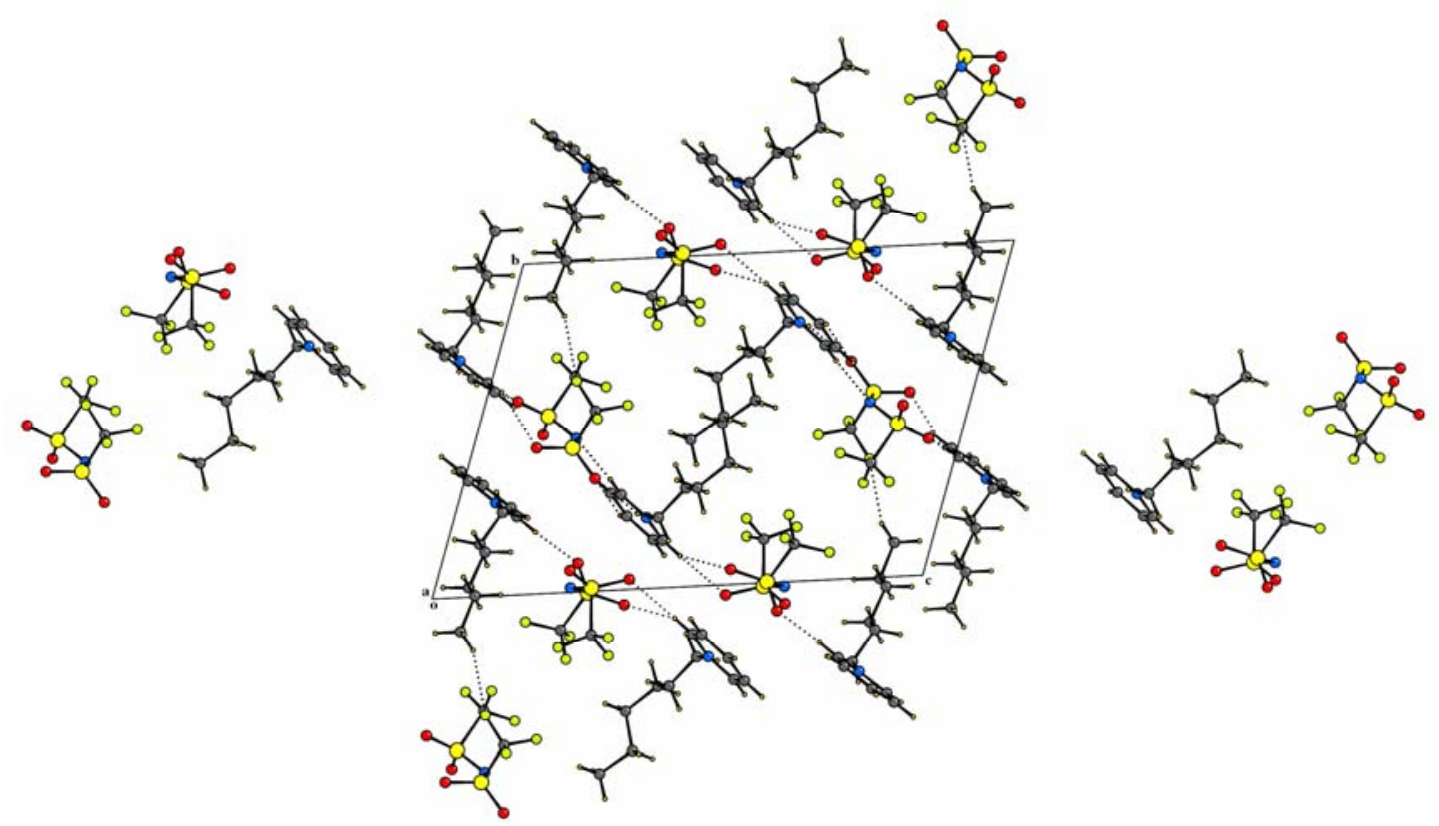

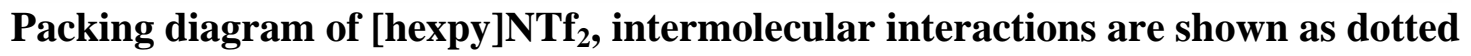
lines 


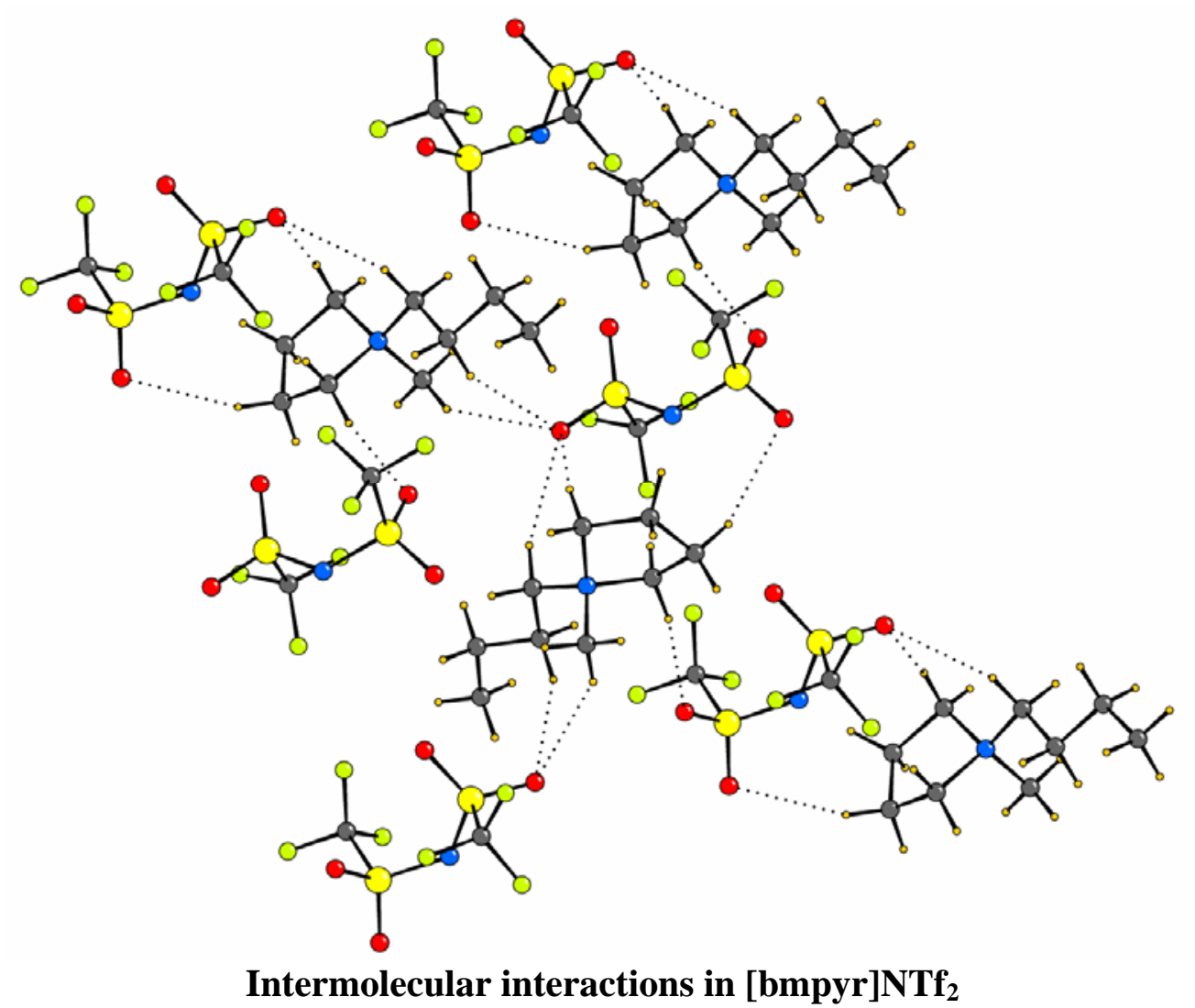


Table 3. 'Ionic liquids', organic molten salts with melting points $<100{ }^{\circ} \mathrm{C}$, ${ }^{\text {(a) }}$ for which single crystal X-ray structure determinations have been reported (up to 18

\section{August 2005).}

\begin{tabular}{|c|c|c|}
\hline m.p. $\left({ }^{\circ} \mathrm{C}\right)$ & Compound $^{(\mathbf{b})}$ & Reference \\
\hline 22 & {$[\mathrm{mmim}] \mathrm{NTf}_{2}$} & J. D. Holbrey et al, Dalton Trans., 2004, 2267. \\
\hline $35-36$ & {$[\mathrm{bmim}] \mathrm{C}_{2} \mathrm{~N}_{5} \mathrm{O}_{4}$} & A. R. Katritzky et al., Chem. Commun., 2005, 868 . \\
\hline 36.7 & {$[\mathrm{emim}][\mathrm{Na}] \mathrm{AlCl}_{4}$} & J. A. Boon et al., J. Chem. Cryst., 1995, 25, 57. \\
\hline 38 & [2-Mebmim] $\mathrm{Fe}_{3} \mathrm{Cl}_{12}$ & P. Kölle et al., Inorg. Chem., 2004, 43, 2803. \\
\hline 38 & {$[\mathrm{emim}] \mathrm{NO}_{3}$} & J. S. Wilkes et al., Chem. Commun., 1992, 965. \\
\hline 40 & {$[2-\mathrm{Mebmim}] \mathrm{BF}_{4}$} & P. Kölle et al., Eur J. Inorg Chem., 2004, 2313. \\
\hline 40 & [2-Mebmim] $\mathrm{PF}_{6}$ & P. Kölle et al., Eur J. Inorg Chem., 2004, 2313. \\
\hline $40-55$ & {$\left[\mathrm{mmpyrr}^{2} \mathrm{NMes}_{2}\right.$} & J.M. Pringle et al., New J. Chem., 2003, 27, 1504. \\
\hline 43 & {$[\mathrm{mmim}] \mathrm{MeOSO}_{3}$} & J. D. Holbrey et al., Green Chem., 2002, 4, 407. \\
\hline 43 & {$[2-\mathrm{Mebmim}] \mathrm{SbF}_{6}$} & P. Kölle et al., Eur J. Inorg Chem., 2004, 2313. \\
\hline 45 & $\left.[\mathrm{emim}] \mathrm{PrCB}_{11} \mathrm{H}_{11}\right]$ & A. S. Larsen et al., J. Am. Chem. Soc., 2000, 122, 7264. \\
\hline 45 & {$[\mathrm{EtOC}(\mathrm{O}) \mathrm{C}(\mathrm{Me}) \mathrm{mim}] \mathrm{NTf}_{2}$} & J. J. Jodry et al., Tett Letters, 2004, 45, 4429. \\
\hline 49 & $\left.[\mathrm{emim}] \mathrm{BuCB}{ }_{11} \mathrm{H}_{11}\right]$ & A. S. Larsen et al., J. Am. Chem. Soc., 2000, 122, 7264. \\
\hline 50 & [2-Mebzeim]NTf ${ }_{2}$ & J.J. Golding et al., Chem. Commun., 1998, 1593. \\
\hline 50 & {$[\mathrm{bmim}] \mathrm{AuCl}_{4}$} & M. Hasan et al., Inorg. Chem., 1999, 38, 5637. \\
\hline 51 & $\left.[\mathrm{mpyrr})_{2}\left(\mathrm{CH}_{2}\right)_{3}\right] \mathrm{Br}_{2}$ & J.L. Anderson, et al., J. Am. Chem. Soc., 2005, 127, 593. \\
\hline 51 & {$[\mathrm{emim}] \mathrm{HF}_{2}$} & K. Matsumoto et al., Solid State Sci., 2002, 4, 23. \\
\hline 55 & {$[\mathrm{emim}] \mathrm{NO}_{2}$} & J. S. Wilkes et al., Chem. Commun., 1992, 965. \\
\hline 57 & [2-Eteeim] $\mathrm{NTf}_{2}$ & J. D. Holbrey et al, Dalton Trans., 2004, 2267. \\
\hline 58 & {$[\mathrm{emim}] \mathrm{AuCl}_{4}$} & M. Hasan et al., Inorg. Chem., 1999, 38, 5637. \\
\hline $58-60$ & {$[\mathrm{emim}] \mathrm{PF}_{6}$} & J. Fuller, et al., Chem. Commun., 1994, 299. \\
\hline 59 & {$[\mathrm{emim}] \mathrm{MeCB}_{11} \mathrm{H}_{11}$} & A. S. Larsen et al., J. Am. Chem. Soc., 2000, 122, 7264. \\
\hline 60 & {$\left[\mathrm{C}_{12} \mathrm{mim}\right] \mathrm{PF}_{6}$} & C. M. Gordon et al., J. Mater. Chem., 1998, 8, 2627. \\
\hline 60.2 & {$\left[\left[\mathrm{Me}_{3} \mathrm{NBH}_{2} \operatorname{mim}\right] \mathrm{NTf}_{2}\right.$} & P. A. Fox et al., Chem. Commun., 2005, 3679. \\
\hline 64 & {$[\mathrm{emim}] \mathrm{EtCB}_{11} \mathrm{H}_{11}$} & A. S. Larsen et al., J. Am. Chem. Soc., 2000, 122, 7264. \\
\hline 66 & {$[\mathrm{bmim}] \mathrm{Cl}$} & J. D. Holbrey et al., Chem. Commun., 2003, 1636. \\
\hline 66 & {$[(\mathrm{hp}) \mathrm{mpyrr}] \mathrm{PF}_{6}$} & J. J. Golding et al., Chem. Mater., 2001, 13, 558. \\
\hline 67 & {$[\mathrm{omim}] \mathrm{CB}_{11} \mathrm{H}_{6} \mathrm{Cl}_{16}$} & A. S. Larsen et al., J. Am. Chem. Soc., 2000, 122, 7264. \\
\hline 70 & [omim] $\mathrm{CB}_{11} \mathrm{H}_{12}$ & A. S. Larsen et al., J. Am. Chem. Soc., 2000, 122, 7264. \\
\hline 70 & {$[\mathrm{emim}]_{2} \mathrm{SO}_{4}$} & J. S. Wilkes et al., Chem. Commun., 1992, 965. \\
\hline 70 & {$[\mathrm{bmim}]_{2} \mathrm{Cu}_{3} \mathrm{Cl}_{8}$} & H. J. Sun et al., Zeit. Krist., 2005, 220, 42. \\
\hline 73 & {$[\mathrm{emim}] \mathrm{Ag}(\mathrm{CN})_{2}$} & Y. Yoshida, et al., Inorg. Chem., 2004, 43, 1458. \\
\hline 78 & {$[2-\mathrm{Mebmim}] \mathrm{HSO}_{4}$} & P. Kölle et al., Inorg. Chem., 2004, 43, 2803. \\
\hline $79-81$ & {$\left[\mathrm{Me}_{3} \mathrm{NH}\right] \mathrm{NTf}_{2}$} & C. M. Forsyth et al., Chem. Mater., 2002, 14, 2103. \\
\hline $85-105$ & [mmpyrr]SCN & J. M. Pringle et al., J. Mater. Chem., 2002, 12, 3475. \\
\hline 87 & {$[\mathrm{emim}] \mathrm{Cl}$} & C. J. Dymek Jr. et al., J. Mol. Struct., 1989, 213, 25. \\
\hline $92-93$ & {$[\mathrm{emim}]_{2} \mathrm{NiCl}_{4}$} & P. B. Hitchcock et al., J. C. S. Dalton Trans., 1993, 2639 \\
\hline
\end{tabular}

(a) The definition of an ionic liquid is arbitrary. Ionic liquids are considered to be salts, usually organic

salts, with melting points below $100^{\circ} \mathrm{C}$. (See J.S. Wilkes, in 'Ionic Liquids in Synthesis', Eds: P. 
Wasserscheid and T. Welton, Wiley VCH, Weinheim, 2002, p1). However, this is not a universal convention.

(b) $[\mathrm{rmim}]=$ 1-alkyl-3-methylimidazolium, r = m (methyl); e (ethyl); b (butyl); o (octyl); $\mathrm{C}_{12}$ (dodecyl); 2Me, 2-Et: imidazolium substituted at the 2-position by methyl, ethyl; [reim] =1-alkyl-3-ethylimidazolium, $\mathrm{r}=\mathrm{e}$ (ethyl); bz (benzyl). [rmpyrr] = 1-alkyl-1-methylpyrrolidinium, r = m (methyl); hp (heptyl). 


\section{Brief survey of literature reports of DSC and related measurement of the ionic liquids investigated in the present study.}

\section{$[\mathrm{emim}] \mathrm{BF}_{4}(\mathbf{1})$}

J.D. Holbrey and K.R. Seddon, J. Chem. Soc., Dalton Trans., 1999, 2133

Reports phase behaviour of salts of the type $\left[C_{n}-m i m\right] B_{4}(n=0-18)$. Those with $n=2-10$ are isotropic liquids at room temperature. For $\mathrm{n}>10$, the materials are low-melting mesomorphous crystalline solids. The melting point of $[\mathrm{emim}] \mathrm{BF}_{4}(\mathrm{n}=2)$ is given as $5.8^{\circ} \mathrm{C}$ (citing other reports giving this value as 12 or $15^{\circ} \mathrm{C}$ ). While no data are presented, the paper describes the materials as showing a strong tendency to supercool, forming glasses with no indication of crystallization. For $\mathrm{n}=0-4$, a glass transition is observed at 'progressively lower temperatures' with a lower limit of $c a-80^{\circ} \mathrm{C}$. No value of $T_{\mathrm{g}}$ for $\mathrm{n}=2$ is presented.

H.L. Ngo, K. LeCompte, L. Hargens and A.B. McEwen, Thermochim. Acta, 2000, 357-358, 97.

A survey of the DSC of 35 imidazolium ionic liquids, including [emim] $\mathrm{BF}_{4}$. (Compounds (2) - (5) were not included.) [emim] $\mathrm{BF}_{4}$ was found to have a melting point (endotherm on heating) of $11^{\circ} \mathrm{C}$ and a freezing point (exotherm on cooling) of $-63{ }^{\circ} \mathrm{C}$. The paper states that 'many of these imidazolium ionic liquids have a glass transition around -80 to $-100^{\circ} \mathrm{C}$ '. No further details for specific compounds are given.

A. B. McEwen, H. L. Ngo, K. LeCompte and J. L. Goldman, J. Electrochem. Soc., 1999, 146, 1687.

A glass transition temperature for $[\mathrm{emim}] \mathrm{BF}_{4}$ of $-95^{\circ} \mathrm{C}$ is reported.

D. Waliszewski, I. Stępniak, H. Piekarski and A. Lewandowski, Thermochim. Acta, 2005, 433, 149.

Presents heat capacity data. 


\section{[bmim] $\mathrm{PF}_{6}$ (2)}

J. G. Huddleston, A.E. Visser, W.M. Reichert, H. D. Willauer, G. A. Broker and R.D. Rogers, Green Chem., 2001, 3, 156.

Physical property and thermochemical data are reported for a series of imidazolium-based ionic liquids, including $\left[\mathrm{bmim} \mathrm{PF}_{6}\right.$. The melting point is given as $10{ }^{\circ} \mathrm{C}$ for a dried sample $(590 \mathrm{ppm}$ water $)$ and $4{ }^{\circ} \mathrm{C}$ for a water equilibrated sample (11700 ppm water). The corresponding glass transition temperatures are $-80^{\circ} \mathrm{C}$ and $-83{ }^{\circ} \mathrm{C}$. Data were collected at a heating/cooling rate of $10^{\circ} / \mathrm{min}$, over the range $-159-+100^{\circ} \mathrm{C}$.

G. J. Kabo, A.V. Blokhin,Y. U. Paulechka, A. G. Kabo, M. P. Shymanovich and J. W. Magee, J. Chem. Eng. Data, 2004, 49, 453.

This paper reports calorimetric measurements leading to thermodynamic parameters for the liquid state. These include determinations of fusion temperature, $T_{\text {fus }}$, of $10^{\circ} \mathrm{C}$ and a $T_{\mathrm{g}}$ of $-97^{\circ} \mathrm{C}$. The authors conclude that the ratio $\mathrm{T}_{\text {fus }} / \mathrm{T}_{\mathrm{g}}$, entropy of fusion and residual entropy for [bmim] $\mathrm{PF}_{6}$ are comparable to values for organic molecules of comparable MWt. However, for some other parameters, [bmim] $\mathrm{PF}_{6}$ is seen to be anomalous. The authors conclude that $\left[\mathrm{bmim} \mathrm{PF}_{6}\right.$ falls somewhere in the mid-range of Angell's fragility index.

Y.U. Paulechka, G.J. Kabo, A.V. Blokhin, O.A. Vydrov, J.W. Magee and M. Frenkel, J. Chem. Eng. Data, 2003, 48, 457

This paper reports calculated thermodynamic parameters. DSC measurements undertaken in range 303-523 ${ }^{\circ} \mathrm{C}$ on a sample certified to contain $<20$ ppm water. 
W. Xu, E. I. Cooper and C. A. Angell, J. Phys. Chem. B, 2003, 107, 6170.

A study of glass transitions (densities, ionic conductivitie and fluidities) for a series ionic liquids (including (2) and (3)) in the context of other glassy materials.

C.P. Fredlake, J.M. Crosthwaite, D.G. Hert, S.N.V.K. Aki and J.F. Brennecke, J. Chem. Eng. Data, 2004, $49,954$.

The paper presents thermochemical data (melting and glass transition temperatures; heat capacities, decomposition temperatures) for 13 imidazolium ionic liquids (including compounds (2) and (3) (q.v.)) DSC measurements were undertaken on carefully dried materials heated and cooled at $10^{\circ} \mathrm{C} / \mathrm{min}$ between $-120-+130{ }^{\circ} \mathrm{C}$. The melting temperature of $\left[\mathrm{bmim}^{2}\right] \mathrm{PF}_{6}$ is given as $11{ }^{\circ} \mathrm{C}$, and a glass transition temperature of $-76^{\circ} \mathrm{C}$. The latter is compared with earlier values from the literature of $-77^{\circ} \mathrm{C}$ (Dzyuba et al., ChemPhysChem., 2002, 3, 161-166) and $-61{ }^{\circ} \mathrm{C}$ (Suarez et al., J. Chim. Phys.-Chim. Biol., 1998, 95, 16261639), noting the likely effect of impurities and experimental conditions on the values determined.

H. Tokuda, K. Hayamizu, K. Ishii, Md. Abu Bin Hasan Susan and M. Watanabe, J. Phys. Chem. B, 2004, $108,16593$.

Temperature dependence of viscosity, density and self-diffusion of a series of [bmim] X studied, where $\mathrm{X}=$ $\mathrm{BF}_{4}, \mathrm{PF}_{6}, \mathrm{OTf}, \mathrm{CF}_{3} \mathrm{CO}_{2}, \mathrm{NTf}_{2}$. Characterisation includes measurement of melting $\left(10^{\circ} \mathrm{C}\right.$; onset of endothermic peak in DSC) and glass transition temperatures $\left(-77^{\circ} \mathrm{C}\right.$; onset of change in heat capacity).

R.G. de Azevedo, J.M.S.S. Esperança, V. Najdanovic-Visak, Z.P. Visak, H.J.R. Guedes, M.N. da Ponte and L.P.N. Rebelo, J. Chem. Eng. Data, 2005, 50, 997.

Pressure dependency of heat capacity, determined from speed of sound measurements; temperature and pressure dependency of density. 


\section{[bmim]OTf (3)}

W. Xu, L.-M. Wang, R.A. Nieman and C.A. Angell, J. Phys. Chem. B, 2003, 107, 11749.

Comparison of orthoborate ionic liquids with OTf and $\mathrm{NTf}_{2}$ salts (including (3)). Density, viscosity and calorimetric measurements described. $\mathrm{Tg}$, Tc and $\mathrm{Tm}$ for (3) are $-81.6,+2.9$ and $+16.4{ }^{\circ} \mathrm{C}$, respectively.

W. Xu, E. I. Cooper and C. A. Angell, J. Phys. Chem. B, 2003, 107, 6170.

A study of glass transitions (densities, ionic conductivitie and fluidities) for a series ionic liquids (including (2) and (3)) in the context of other glassy materials.

C.P. Fredlake, J.M. Crosthwaite, D.G. Hert, S.N.V.K. Aki and J.F. Brennecke, J. Chem. Eng. Data, 2004, $49,954$.

The melting and freezing temperatures of (3) were found to be 13 and $-19^{\circ} \mathrm{C}$, respectively.

H. Tokuda, K. Hayamizu, K. Ishii, Md. Abu Bin Hasan Susan and M. Watanabe, J. Phys. Chem. B, 2004, $108,16593$.

A melting temperature of $17^{\circ} \mathrm{C}$ was observed for (3) (the onset temperature of an endothermic peak in DSC).

\section{[[hexpy]NTf 2 (4)}

J.M. Crosthwaite, M.J. Muldoon, J.K. Dixon, J.L. Anderson and J.F. Brennecke, J. Chem.

Thermodynamics, 2005, 37, 559. 
43 ionic liquids studied (the first significant study of pyridinium based compounds, but also including [hmim] and [omim] salts). Viscosities, heat capacities, decomposition, melting, fusion and glass transition temperatures. (4) is reported to melt at $0{ }^{\circ} \mathrm{C}$ and to undergo a glass transition at $-77^{\circ} \mathrm{C}$.

[bmpyr]NTf 2 (5)

None reported. 